\title{
Restriction fragment length polymorphism analysis of genes of virulent strain isolate of Toxoplasma gondii using enzyme DdeI
}

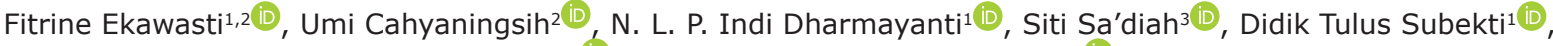 \\ Zul Azmi ${ }^{1}$ and Muhammad Ibrahim Desem ${ }^{1}$ (D)
}

\begin{abstract}
1. Indonesian Research Center for Veterinary Sciences, Indonesia Agency Agriculture Research and Development, Agricultural of Ministry, Bogor, 16167, Indonesia; 2. Department of Animal Infectious Diseases and Veterinary Public Health, Faculty of Veterinary Medicine, IPB University, Bogor, 16680, Indonesia; 3. Department of Anatomy, Physiology, and Pharmacology, Faculty of Veterinary Medicine, IPB University, Bogor, 16680, Indonesia.

Corresponding author: Umi Cahyaningsih, e-mail: umicahyaningsih@yahoo.co.id

Co-authors: FE: fitrineekawasti@gmail.com, NLPID: nlpdharmayanti@gmail.com, SS: sitisa@apps.ipb.ac.id, DTS: subektididik96@yahoo.com, ZA: zulazmi23@gmail.com, MID: muhammad.desem@gmail.com Received: 09-05-2021, Accepted: 23-08-2021, Published online: 13-10-2021
\end{abstract}

doi: www.doi.org/10.14202/IJOH.2021.196-203 How to cite this article: Ekawasti $F$, Cahyaningsih $U$, Dharmayanti NLPI, Sa'diah S, Subekti DT, Azmi Z, Desem MI (2021) Restriction fragment length polymorphism analysis of genes of virulent strain isolate of Toxoplasma gondii using enzyme DdeI, Int. J. One Health, 7(2):196-203.

\begin{abstract}
Background and Aim: Toxoplasma gondii is a unicellular coccidian parasite distributed globally and is an important zoonotic pathogen. Approximately $30 \%$ of the human population worldwide is chronically infected with $T$. gondii. The pathogenicity of this species depends on the type originating from the clonal population. Techniques for more accurately determining the type of $T$. gondii have recently been developed using genetic markers. Specifically, $T$. gondii has been typed using polymerase chain reaction-restriction fragment length polymorphism (PCR-RFLP). This study aimed to identify sets of PCR-RFLP markers that have high power to discriminate genotyping of $T$. gondii and are easy to use and are easy to use. The objective of this study was to characterize virulent strain isolates of $T$. gondii by PCR-RFLP using 10 markers with DdeI.

Materials and Methods: T. gondii tachyzoites (RH virulent strain) were derived from culture cells at the Indonesian Research Center for Veterinary Sciences. Genotyping was performed on T. gondii DNA extracted from cell cultured tachyzoites using 10 genetic markers of PCR-RFLP, namely, B1\#1, B1\#2, B1\#3, SAG1\#1, SAG1\#2, P30, BAG1, ROP1, $G R A 1$, and GRA7, with digestion using the restriction enzyme DdeI.

Results: The 10 genes were amplified by PCR. Among them, three genetic markers, B1\#3, ROP1, and GRA1, were genotyped by the PCR-RFLP using restriction enzyme DdeI. Overall, the findings showed that the specific RFLP profile of digestion of gene regions by DdeI could be used as a specific marker for the virulent biotype causative of toxoplasmosis. In addition, virulent strains of $T$. gondii can be easily detected by these markers.

Conclusion: Three pairs of primers (B1\#3, ROP1, and GRA1) with DdeI have proven useful for the diagnosis of acute toxoplasmosis (virulent strain biotype I). This proposed method is relatively simple, rapid, cheap, and can be performed in most laboratories, providing a practical approach for the routine analysis of $T$. gondii strains.
\end{abstract}

Keywords: DdeI, genotype, restriction enzyme, Toxoplasma gondii.

\section{Introduction}

Toxoplasma gondii is one of the most common zoonotic diseases. This parasite can infect a wide range of warm-blooded animals and is estimated to chronically infect $30-50 \%$ of the human population globally [1-3]. The main factors associated with the great variability in the distribution of $T$. gondii infection are socioeconomic, environmental, and cultural, as well as lifestyle and eating habits [4]. In Indonesia, it is common to consume goat, sheep, beef, chicken, and rabbit satay, potentially infected with cysts present in undercooked meat accompanied by raw vegetables.

Copyright: Ekawasti, et al. This article is an open access article distributed under the terms of the Creative Commons Attribution 4.0 International License (http://creativecommons.org/licenses/ by/4.0/), which permits unrestricted use, distribution, and reproduction in any medium, provided you give appropriate credit to the original author(s) and the source, provide a link to the Creative Commons license, and indicate if changes were made. The Creative Commons Public Domain Dedication waiver (http:// creativecommons.org/ publicdomain/zero/1.0/) applies to the data made available in this article, unless otherwise stated.
Moreover, oral contact with sporulated oocysts from feces of infected cats is another potential infection route $[5,6]$.

The prevalence of $T$. gondii in the human population in Indonesia, one of the countries most intensely affected by this parasite, is estimated to be around $50 \%$ [7]. The seroprevalence of toxoplasmosis was reported to be $62.5 \%(394 / 630)$ and $67.7 \%(107 / 158)$ in Central Java and Yogyakarta, respectively $[7,8]$. In North Sulawesi, a high prevalence $(58.5 \%$; 501/856) was also reported in humans, but the rate was only $2.3 \%$ in pigs [7]. Meanwhile, seroprevalence was reported as $14.6 \%$ in pigs and $7.4 \%$ in cattle in West Java [9]. Clinically, among HIV-infected patients, $32.8 \%$ gave positive results by polymerase chain reaction (PCR) using cerebrospinal fluid, although circulating toxoplasma immunoglobulin $\mathrm{G}$ was present in $77.2 \%$ of patients in 1994 in West Java Province [10]. In addition, Lestari et al. [11] reported that 26 (8.4\%) of 311 HIV patients were diagnosed with toxoplasma 
chorioretinitis in 2013. More research and efforts by governmental and non-governmental authorities are required to minimize the rates of infection.

T. gondii is known to cause great economic losses in the livestock industry due to abortion, prematurity, and stillbirth. Infection with $T$. gondii in humans is usually asymptomatic, but the infection may cause abortion in pregnant women or occasionally toxoplasmic encephalitis [12]. T. gondii has been considered a single species within the genus Toxoplasma. However, within T. gondii population, there are various strains with different virulence levels. The virulence of the strains is usually determined on the basis of the lethal dose of tachyzoites. On the basis of lethal doses and tachyzoite virulence for mice, different strains of $T$. gondii were divided into two groups: Virulent strains (LD100 $<10$ tachyzoites), which can cause acute lethal infection with ascites in mice; and avirulent strains (LD100 $>10^{3}$ tachyzoites), which can cause chronic infection typified by the formation of tissue cysts in mouse brain [13].

The consequences of infection with $T$. gondii may depend on the parasite's genotype and the host species. In humans, disease manifestations range from asymptomatic to severe acute toxoplasmosis $[5,14]$. Clinical symptoms of $T$. gondii infection are non-specific and unreliable for diagnosis. The detection of T. gondii infection by molecular methods is appealing due to their high sensitivity and specificity $[15,16]$. Most T. gondii isolates from human and animal sources have been grouped into one of the three clonal lineages by PCR-restriction fragment length polymorphism (RFLP) [17]. In addition, there is increasing interest in the biological differences among different genotypes of T. gondii (biotypes I, II, and III) [18].

The diagnosis of $T$. gondii infection by direct detection of parasite-specific DNA in biological samples using PCR-based molecular methods has gained popularity. The molecular diagnosis is more sensitive and cost-effective than conventional methods [14,19]. More detailed differentiation of the strains can be achieved by RFLP using various enzymes [20]. The method most commonly used for these purposes is multilocus PCRRFLP. Genetic polymorphism of different $T$. gondii strains and isolates with regard to their virulence was studied by PCR-RFLP with the following markers with the enzyme Ddel [21]. The DdeI restriction enzyme is a cheap option for detecting variant alleles. The amplified product is restricted by the DdeI enzyme, which recognizes the cutting site. DdeI produces a polymorphic digestion pattern from the PCR product that discriminates the virulent RH strain of $T$. gondii as biotype I. It was categorized as having an acutely virulent phenotype by PCR-RFLP-based genotype characterization [20].

Howe and Sibley [13] used PCR-RFLP (DdeI) to characterize the differences between avirulent and virulent strains. The DNA target regions used in that study are important for $T$. gondii, including the genes B1\#1, B1\#2, B1\#3, SAG1\#1, SAG1\#2, P30, BAG1, ROP1, and GRA1 [21-23]. PCR-RFLP capable of distinguishing the alleles in one restriction enzyme reaction by agarose gel electrophoresis [24].

This highlights the need to develop sets of markers that can provide higher resolution for T. gondii genotyping. This study aimed to identify sets of PCRRFLP markers that have high discriminatory power and are easy to use. The objective of this study was to characterize virulent strain isolates of $T$. gondii by PCR-RFLP using 10 markers with DdeI.

\section{Materials and Methods}

\section{Ethical approval}

Ethical approval is not needed for this study. Tachyzoite isolates from liquid nitrogen were utilized as samples.

\section{Study period and location}

The study was conducted in January 2021. The samples were processed at the Indonesia Research Center for Veterinary Sciences.

\section{DNA isolation}

T. gondii tachyzoites (RH virulent strain) were derived from cultured cells at the Indonesia Research Center for Veterinary Sciences. The DNA of $T$. gondii was extracted from an isolate stored in liquid nitrogen. The DNA template was extracted using the PureLink ${ }^{\mathrm{TM}}$ Genomic DNA Mini Kit (Invitrogen, USA). Purification and concentration of the DNA extracts for DNA quantification were performed using Thermo Scientific NanoDrop Products, and extracts were stored at $-20^{\circ} \mathrm{C}$ before PCR testing [25].

\section{Genetic markers}

The 10 genetic markers used in this study were $B 1$ (\#1, \#2, and \#3), SAG1 (\#1 and \#2), P30, ROP1, BAG1, GRA1, and GRA7. The primers used are presented in Table-1 (all sequences in 5'-3' orientation) [21-23,26-30].

\section{PCR}

PCR was carried out using 10 genes. DNA of $T$. gondii was detected by amplification in nested PCR (nPCR) for five genes, namely, $B 1$ (\#1, \#2, and \#3) and SAG1 (\#1 and \#2), and by single PCR (PCRs) for five genes, namely, P30, ROP1, BAG1, GRA1, and GRA7. PCR was carried out in a Thermo Scientific ${ }^{\mathrm{TM}}$ Arktik $^{\mathrm{TM}}$ Thermal Cycler (Thermo Fisher Scientific, Finland). The steps of the nPCR and PCRs assays were performed using $25 \mu \mathrm{L}$ reactions containing $1 \mu \mathrm{L}$ of DNA template, $0.25 \mathrm{M}$ primer, $1.5 \mathrm{mM}$ $\mathrm{MgCl}_{2}, 0.01 \mathrm{U}$ Taq DNA polymerase, and $0.2 \mathrm{mM}$ dNTP. Amplification conditions were 35 cycles of $95^{\circ} \mathrm{C}$ for $1 \mathrm{~min}, 58^{\circ} \mathrm{C}$ for $1 \mathrm{~min}$, and $72^{\circ} \mathrm{C}$ for $2 \mathrm{~min}$. Electrophoresis for PCR products was performed using 1.5\% agarose and SYBR ${ }^{\circledR}$ Safe DNA Gel Stain (Thermo Fisher Scientific, Finland), run at $100 \mathrm{~V}$. The bands were visualized using a UV transilluminator.

\section{DNA sequencing}

PCR products from amplification of the gene target regions were sequenced and identified. PCR 
Table-1: The sets of Toxoplasma gondii gene primers.

\begin{tabular}{|c|c|c|c|}
\hline No. & Primer & References & Nucleotides \\
\hline 1 & B1 (\#1) & [21] & $\begin{array}{l}\text { F1 CGACAGAAAGGGAGCAAGAG } \\
\text { R1 ACGGATGCAGTTCCTITCTG } \\
\text { F2 CCGGGCAAGAAAATGAGAT } \\
\text { R2 CATGGTITGACTITTGGG }\end{array}$ \\
\hline 2 & B1 (\#2) & {$[26]$} & $\begin{array}{l}\text { F1 TGTTCTGTCCTATCGCAACG } \\
\text { R1 ACGGATGCAGTTCCTITCTG } \\
\text { F2 TCTTCCCAGACGTGGATTTC } \\
\text { R2 CTCGACAATACGCTGCTTGA }\end{array}$ \\
\hline 3 & B1 (\#3) & [27] & $\begin{array}{l}\text { F1 GGAACTGCATCCGTTCATGAG } \\
\text { R1 TCTITAAAGCGTTCGTGGTC } \\
\text { F2 TGCATAGGTTGCAGTCACTG } \\
\text { R2 GGCGACCAATCTGCGAATACACC }\end{array}$ \\
\hline 4 & SAG1 (\#1) & {$[26]$} & $\begin{array}{l}\text { F1 GTTCTAACCACGCACCCTGAG } \\
\text { R1 GTGGTTCTCCGTCGGTGTGAG } \\
\text { F2 CAATGTGCACCTGTAGGAAGC } \\
\text { R2 TTATCTGGGCAGGTGACAAC }\end{array}$ \\
\hline 5 & SAG1 (\#2) & [23] & $\begin{array}{l}\text { F1 CACCTGTAGGAAGCTGTAGTCACTG } \\
\text { R1 TCACTGTGACCATACAACTCTGTG }\end{array}$ \\
\hline 6 & P30 & [28] & $\begin{array}{l}\text { F CACACGGTTGTATGTCGGTTTCGCT } \\
\text { R TCAAGGAGCTCAATG TTACAGCCT }\end{array}$ \\
\hline 7 & BAG1 & [23] & $\begin{array}{l}\text { F AGGAGAGAAGACCTCGAAAGAAG } \\
\text { R TGAACGCTAGGTITCTGGATACG }\end{array}$ \\
\hline 8 & ROP1 & [29] & $\begin{array}{l}\text { F CGTGACATATACTGCACTGAC } \\
\text { R CATCGTCAAACTCGATCAC }\end{array}$ \\
\hline 9 & GRA1 & {$[22]$} & $\begin{array}{l}\text { F CGGTITGCTTGTGTTGTITG } \\
\text { R CATGGGGTACGATCACAACA }\end{array}$ \\
\hline 10 & GRA7 & {$[30]$} & $\begin{array}{l}\text { F GCGGATCCGCCACCGCGTCAGATGAC } \\
\text { R CGGGATCCCTACTGGCGGGCATCCTC }\end{array}$ \\
\hline
\end{tabular}

products were sequenced by Bioneer Sequencing. DNA sequences were analyzed using CLC Sequence Viewer Version 8.0 software (Qiagen, Denmark) (https://clcsequence-viewer.software.informer.com/8.0/).

\section{RFLP}

The products of PCR were digested by DdeI restriction enzymes to identify diagnostic restriction fragments [21]. The procedure for enzyme treatment was conducted according to the protocol of the enzyme DdeI (Promega), in line with the manufacturer's instructions. Ten microliters of PCR product $(1 \mu \mathrm{L}$ DNA $1 \mu \mathrm{g} / \mu \mathrm{L})$ were mixed with $16.3 \mu \mathrm{L}$ of sterile deionized water, $2 \mu \mathrm{L}$ of $10 \times \mathrm{RE}$ buffer (composed of $60 \mathrm{mM}$ Tris- $\mathrm{HCl} \mathrm{pH} 7.9,1.5 \mathrm{M} \mathrm{NaCl}, 60 \mathrm{mM}$ $\mathrm{MgCl}_{2}$, and $10 \mathrm{mM} \mathrm{DTT}$ at $37^{\circ} \mathrm{C}$ ), $0.2 \mu \mathrm{L}$ of $10 \mu \mathrm{g} /$ $\mu \mathrm{L}$ acetylated BSA, and $0.5 \mu \mathrm{L}$ of restriction enzyme DdeI (10 U/ $\mu \mathrm{L})$ (Promega). The mixtures were incubated at $37^{\circ} \mathrm{C}$ for approximately $1.5 \mathrm{~h}$. The digested PCR products were analyzed on a $1.5 \%$ agarose gel and subjected to SYBR ${ }^{\mathrm{TM}}$ safe staining, run at $100 \mathrm{~V}$. The bands of the restriction patterns were visualized using a UV transilluminator.

\section{Results and Discussion}

T. gondii infects one-third of the human population globally [31]. Serological methods are standard approaches for detecting toxoplasmosis. In these cases, to confirm the diagnosis, cell culture-based molecular techniques such as PCR are employed [32]. PCR, in which a segment of the genome of $T$. gondii can be detected because of this approach's sensitivity and specificity, is preferred over other techniques [33].
Although the genus Toxoplasma consists of just a single species, T. gondii, molecular biology tools have provided evidence of three distinct clonal lineages in this species [34,35]. PCR-RFLP allows amplification of a conserved region of the DNA sequence using PCR to detect the genetic strains within species by digesting the amplified product into fragments through certain restriction enzymes. This technique has been used for specialization by exploiting DNA sequence variation within mitochondrial DNA [36].

RFLP-based analysis is a popular technique for genotyping [37]. In this study, 10 standard markers were used: $B 1$ (\#1, \#2, and \#3), SAG (\#1 and \#2), P30, BAG1, ROP1, GRA1, and GRA7. They have been frequently used for genotyping isolates worldwide $[14,23,26]$. In addition, $B A G 1$ has been described as one of the most abundant bradyzoite-specific genes found in T. gondii [38]. One reason for the success of $T$. gondii in achieving infection and avoiding the host immune system is its ability to modify the vacuole parasitophorous (VP), thereby avoiding lysosome recognition. The key to modifying the VP lies in a secretory protein in the form of a granular protein (GRA), roptri protein (ROP). ROP proteins play a role early in invasion, and GRA plays a role in VP development. The GRA protein continues to be secreted along with the enlargement of the VP and the increase in $T$. gondii so that the gene encoding the GRA1 protein is often used as a marker for identifying the life of $T$. gondii both in the tachyzoite and bradyzoite phases [23]. Most investigators have used these genes for detecting strain types of $T$. gondii $[39,40]$. 
The genes of $B 1, S A G 1, P 30, B A G 1, R O P 1$, GRA1 and GRA7 are specific and the most sensitive for detecting T. gondii [41-44]. The proposed method was revealed to be highly sensitive and specific in detecting the virulent strain of $T$. gondii by PCR-RFLP of $B 1$ (\#1, \#2, and \#3), SAG (\#1 and \#2), P30, BAG1, $R O P 1$, and GRA1. Their overlap in the restriction enzyme DdeI reaction by PCR-RFLP can be predicted by in silico analysis using the gene sequences, and the actual reaction can be seen from visualizing the results of gel electrophoresis.

\section{In silico restriction gene analysis}

Using in silico restriction digestion of given DNA sequences to predict the expected DNA fragments, the "digestDNA" function can be used to perform the digestion [45]. In silico analysis is an approach performed on a computer to analyze the restriction fragment length distribution. In silico restriction digestion sites could comparison of restriction patterns for two or more DNA sequences. In this study, we used CLC Sequence Viewer Version 8.0 software (Table-2).

In silico restriction gene programs searching for restriction sites, when it comes into contact with a DNA sequence with a shape that matches part of the enzyme, called a recognition site, it wraps around the DNA and breaks both strands of the DNA molecule. DdeI is a common restriction enzyme used in laboratories. PCR follows with RFLP for DNA fragmentation techniques have been frequently used for genetic characterization of T. gondii [46]. In silico analysis reaction by sequences gene of PCR products. These genes are cut with the restriction enzyme DdeI depending on the cutting site, which produces differences in the size of the DNA fragments. The DdeI restriction cuts $5^{\prime} \ldots$ C $\downarrow$ TNAG .... $3^{\prime}$ and $\uparrow 3^{\prime} \ldots$ GANT $\uparrow C \ldots 5^{\prime}$ sites as indicated by the arrows(Table-2).

A generally used genome fragmentation method, restriction endonuclease digestion may severely compromise genomic mapping resolution and prevent the practical annotation of certain chromosomal regions. In silico restriction enzyme digests to minimize mapping bias in genomic sequencing and result in proper DNA fragment size distributions and optimal resolution in genomic sequencing technologies [45]. In general, In silico analysis is predicts their visualization in the experiment. The availability of the $T$. gondii genome sequence, these approaches can be readily characterized and optimized via in silico modeling [47].

\section{PCR-RFLP analysis}

T. gondii isolates in this study were subjected to PCR with 10 different primers simultaneously, using the same duration, temperature, and PCR cycling. Based on the results of electrophoresis (Figure-1), all DNA samples from $T$. gondii virulent isolate were amplified. PCR-RFLP was performed with the restriction enzyme DdeI; among the 10 genetic markers of $T$. gondii, only three genes (B1 \#3, ROP1, and GRA1) could produce overlap in the fragmentation pattern. DdeI produced a polymorphic digestion pattern from the PCR product that discriminated the virulent $\mathrm{RH}$ strain of T. gondii as Type I. PCR-RFLP of T. gondii genes using the DdeI enzyme produced site fragment pattern [46]. Cleavage of the DNA repeats resulted in the formation of bands on agarose electrophoresis gels. Direct analysis of the DNA repeats appears to be a simple method of obtaining a digestion pattern

Table-2: In silico restriction site analysis of genes sequences digested using enzyme DdeI.

\begin{tabular}{|c|c|c|c|c|c|}
\hline \multirow{3}{*}{$\begin{array}{l}\text { No. } \\
1\end{array}$} & \multirow{3}{*}{$\begin{array}{l}\text { Genes } \\
B 1 \# 1\end{array}$} & \multirow{3}{*}{$\begin{array}{c}\begin{array}{c}\text { Amplicon size } \\
\text { (bp) }\end{array} \\
191\end{array}$} & \multirow{3}{*}{$\begin{array}{l}\text { primers } \\
B 1 \# 1-F \\
B 1 \# 1-R\end{array}$} & \multicolumn{2}{|c|}{$\begin{array}{c}\text { DdeI } \\
5^{\prime} \ldots \text {... } \downarrow \text { TNAG...3' } \\
3^{\prime} \ldots \text { ANT } \uparrow \text { C....5' }\end{array}$} \\
\hline & & & & - & - \\
\hline & & & & 2 & 85,139 \\
\hline \multirow[t]{2}{*}{2} & B1 \#2 & 508 & $\mathrm{~B} 1 \# 2-\mathrm{F}$ & - & - \\
\hline & & & $\mathrm{B} 1 \# 2-\mathrm{R}$ & - & - \\
\hline \multirow[t]{2}{*}{3} & B1 \#3 & 967 & B1\#3-F & 3 & 93, 113, 774 \\
\hline & & & $\mathrm{B} 1 \# 3-\mathrm{R}$ & 4 & $2, \mathbf{1 4 8}, 809,829$ \\
\hline \multirow[t]{2}{*}{4} & SAG1 \# 1 & 460 & SAG1\#1-F & - & - \\
\hline & & & SAG1\#1-R & - & - \\
\hline \multirow[t]{2}{*}{5} & $S A G 1 \# 2$ & 341 & SAG1\#2-F & - & - \\
\hline & & & SAG1\#2-R & - & - \\
\hline \multirow[t]{2}{*}{6} & P30 & 340 & P30-F & - & - \\
\hline & & & P30-R & - & - \\
\hline \multirow[t]{2}{*}{7} & $B A G 1$ & 460 & BAG1-F & 1 & 32 \\
\hline & & & BAG1-R & 1 & 389 \\
\hline \multirow[t]{2}{*}{8} & $R O P 1$ & 1220 & ROP1-F & 1 & 767 \\
\hline & & & ROP1-R & 3 & $\mathbf{6 1 3}, 1122,1196$ \\
\hline \multirow[t]{2}{*}{9} & GRA1 & 802 & GRA1-F & 3 & 3, 159, 187 \\
\hline & & & GRA1-R & 2 & 573,601 \\
\hline \multirow[t]{2}{*}{10} & GRA7 & 616 & GRA7-F & 1 & 29 \\
\hline & & & GRA7-R & 1 & 530 \\
\hline
\end{tabular}

Blue $=$ Primer size was determined from sequence between $5^{\prime}$ forward and $3^{\prime}$ reverse primer annealing position in this study. Bold $=$ The fragments present in electrophoresis gel 


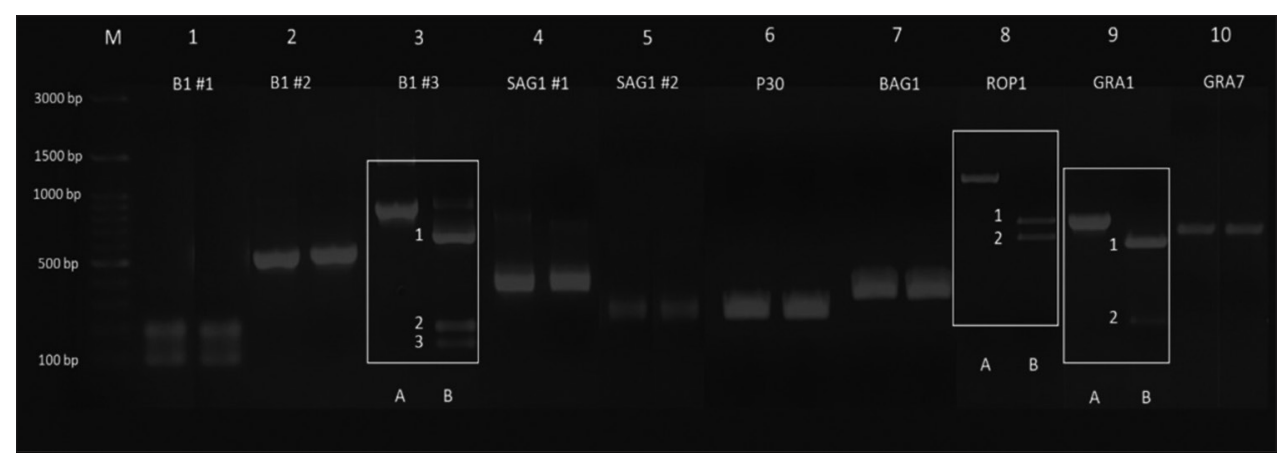

Figure-1: Toxoplasma gondii nucleic acid amplified by various gene targets. Polymerase chain reaction-restriction fragment length polymorphism (PCR-RFLP) patterns of T. gondii virulent strain of B1 (\#1, \#2, and \#3), SAG1 (\#1 and \#2), P30, $B A G 1, R O P 1, G R A 1$, and GRA7 cut with DdeI. The PCR product was resolved on $1.5 \%$ agarose stained with SYBR ${ }^{T M}$ safe staining. Lane M: Geneaid 100 bp DNA ladder, A: PCR conventional, B: Restriction pattern of PCR-RFLP (1, 2, and 3).

in silico, but its use may produce incorrect results due to the rather high variability of the nucleotide sequence in these DNA regions [47]. The patterns we obtained in RFLP analysis were different from those previously in silico restriction reported $[42,44]$. We identified the RFLP pattern for the genotype confirmed by in silico analysis, and the result turns out that some show a different pattern. RFLP analysis does not allow evaluation of the number of obtained DNA fragments of a given length or presence of fragments lacking DdeI sites that do not allow fragment separation. This led us to propose an in silico restriction analysis as support for a large number of sequences for $T$. gondii genotypes.

\section{Characterization of $B 1$ genes}

Many researchers have used the $B 1$ gene as a marker because it, providing significant representation of several isolates, making it highly sensitive and specific for detecting $T$. gondii $[15,21,26]$. Therefore, many primers are designed based on the $B 1$ gene target. In this study, primers for three different $B 1$ genes $(B 1 \# 1$, $B 1 \# 2$, and $B 1 \# 3$ ) were used. Based on the PCR results, the three primers of the $B 1$ gene successfully achieved amplification, but after being digested by the enzyme, not all $B 1$ genes showed overlapping fragments.

T. gondii nucleic acid amplified by various gene targets. PCR-RFLP patterns of T. gondii virulent strain of $B 1$ (\#1, \#2, and \#3), SAG1 (\#1 and \#2), P30, BAG1, ROP1, GRA1, and GRA7 cut by DdeI. (Figure-1). This pattern of the isolate was the same as the pattern obtained by the same method performed in 1998, when this isolate was first genotyped [46]. The origin of the same target gene but with a different arrangement of the primary genes created a discrepancy in the results. In addition, most of the highly repetitive markers that provide sensitive detection $(B 1)$ are not useful for genotyping the parasite due to a relative absence of polymorphisms [35]. Accordingly, to identify the capacity of a pair of primers, it is necessary to evaluate the results of DNA sequencing and optimize the applied method.

\section{Analysis of genes with incomplete or no digestion}

Based on this study, not all genes that were successfully amplified by PCR could be digested by PCR-RFLP using the restriction enzyme DdeI.

\section{Analysis of genes with no fragment separation}

Based on this study, not all genes were successfully amplified by PCR-RFLP using the restriction enzyme DdeI. From Figure-1 and Table-2, it can be seen that, on in silico analysis, gene Bl\#1 showed two restriction sites for each of the primer B1\#1-R (85 bp and $139 \mathrm{bp}$ ), BAG1-FR gene (32 bp and $389 \mathrm{bp}$ ), and GRA7-FR gene (29 bp and $530 \mathrm{bp}$ ). Meanwhile, on the electrophoresis gel, the $B 1 \# 1$ gene, $B A G 1$ gene, and GRA7 gene did not show any restriction fragment pattern. This means that no digestion occurred, which can also be seen from the same size of bands between the PCR and RFLP results. The B1\#3 gene, ROP1 gene, and GRA1 gene showed different fragment patterns among in silico restriction and RFLP analyses (Table- 2 and Figure-1). The difference in results regarding the restriction sites from the in silico prediction analysis and electrophoresis was due to incomplete digestion. Incomplete digestion is the most commonly occurring reaction in PCR-RFLP.

Many factors can affect the reaction. These include (1) the size of DNA fragment. Another important factor is (2) the optimization method. The ratio of enzyme to DNA might not be suitable as the concentration of PCR product was not measured. As in enzyme protocol mentioned, the reaction is placed 1-4 h. It is possible that the digestion process required further optimization. A further factor is (3) low-molecular-weight fragments. The absence of fragments might be due to the conditions or digestion time not being optimal or there being a very low concentration, resulting in no detection in the electrophoresis gel [48]. In addition, (4) PCR cycles can affect the reaction. More cycles might be needed or the PCR might require improvement to generate more products. Moreover, (5) the voltage for electrophoresis could have an effect. The gel could be run at half the current voltage or imaged at an early stage to obtain a better view [49]. Finally, (6) the loading buffer could be influential. Four microliters of $6 \times$ loading buffer could be used, allowing DNA overlaps to be seen clearly. Note that overnight digests are usually unnecessary and may result in DNA degradation [50]. 
In addition, a set of reference $T$. gondii isolates should be included to monitor the efficiency of PCR amplification and restriction enzyme digestion. This is very important because, for each batch of experiments, there can be variation in the efficiency of restriction digestion and sometimes incomplete digestion can occur. Moreover, the concentration of electrophoretic gel can also vary slightly among experiments. In this technique, a PCR amplicon is treated by a certain RE that cuts the DNA at a unique restriction site, known as a recognition site, to generate several DNA fragments of various sizes. Subsequently, the digested amplicons are loaded onto a gel, to which an electric field is applied. The differently sized bands will move at varying distances across the gel [51].

\section{Restriction enzyme does not cut DNA}

SAG1 (\#1 and \#2), P30 (SAG1), and B1\#2 genes are commonly used in RFLP for detecting strains of T. gondii. SAG1 is the major surface molecule of T. gondii, which is an important ligand for attaching to host cells [52]. SAG1, which is regularly used as a marker, clearly indicated the presence of Type I by RFLP with DdeI in previous studies [21,53]. However, based on this study, that gene was not digested by DdeI, and there was no restriction site in either in silico analysis or gel electrophoresis.

If there are no issues with digesting the DNA, there may be something else wrong with the reaction set-up. Several factors can affect the reaction, including the preparation of DNA to be cleaved, which should be free of contaminants such as phenol, chloroform, alcohol, EDTA, detergents, or excessive salts, all of which can interfere with the activity of the restriction enzyme. The experimental DNA can be incubated in reaction buffer without restriction enzyme (degradation of DNA indicates contamination of the DNA preparation or reaction buffer), along with an analysis of control DNA with restriction enzyme, to more accurately judge whether the reaction was successfully completed. If the control DNA is cleaved and the experimental DNA resists cleavage, the two DNAs can be mixed to determine whether an inhibitor is present in the experimental sample. If an inhibitor (often salt, EDTA, or phenol) is present, the control DNA will not be cut after mixing [50].

DdeI can fail to cutDNA because the DNA sequence does not match this restriction enzyme. If the amplified product is cut with the DdeI enzyme, recognition of the cutting site has occurred. The restriction enzyme recognizes just one or a few restriction sites. DdeI will cut at sites of $5^{\prime} \ldots \mathrm{C} \downarrow \mathrm{TNAG} \ldots 3^{\prime}$ and $3^{\prime} \ldots$ GANT $\uparrow C \ldots 5^{\prime}$. When it finds its target sequence, a restriction enzyme will make a double-stranded cut in the DNA molecule, but if the DNA sequence has a shape that does not match part of the enzyme, it will not be cut. The most powerful feature of PCR-RFLP is its simplicity. PCR-RFLP can be performed without the need for considerable experience in molecular biology. However, despite the ease of use and extreme simplicity of PCR-RFLP, it is limited to use only with the recognition site of the restriction enzyme (Table-2 and Figure-1), so a specific restriction enzyme must be used.

Overall, the pattern of fragments can be used as a standard for genotype sensitivity and specificity. RFLP is a type of polymorphism that results from variation in the DNA sequence recognized by restriction enzymes. Genotyping of $T$. gondii using multilocus PCR-RFLP markers is a high-resolution and simple method for identifying parasites [24]. The recent development of PCR-RFLP makes it possible to genetically characterize or classify $T$. gondii from biological samples at high resolution [5]. Findings clearly show that gene target loci can be used to discriminate genotypes of $T$. gondii [15]. Based on the results, the genetic markers of $B 1 \# 3, R O P 1$, and GRAl can be used in PCR-RFLP using restriction enzyme DdeI for genotyping of $T$. gondii. More research is needed to compare many isolated samples, other genetic markers, and other restriction enzymes.

\section{Conclusion}

The specificity and sensitivity of a variety of PCR-RFLP methods for diagnosing infection with virulent strains of $T$. gondii are dependent on several factors, including the primer gene target and restriction enzyme. Three pairs of primers $(B 1 \# 3, R O P 1$, and $G R A 1$ ) with DdeI have proven useful for this purpose, and this approach can be used for the rapid diagnosis of acute toxoplasmosis (virulent strain biotype I). PCR-RFLP is specific, sensitive, easy to perform, and ready to be adopted for the diagnosis and genotyping of $T$. gondii. Our results indicate that this approach can be used worldwide on appropriate standardization. This proposed method is relatively simple, rapid, cheap, and can be performed in most laboratories as a practical approach for the routine analysis of $T$. gondii.

\section{Authors' Contributions}

FE, UC, NLPID, and SS: Conceptualized and designed the study. FE, DTS, ZA, and MID: Data collection. FE and DTS: Data analysis and review of data for critical intellectual content. All authors read and approved the final manuscript.

\section{Acknowledgments}

The authors acknowledge the Indonesian Research Center for Veterinary Sciences, Indonesia Agency Agriculture Research and Development for financial support in APBN Project (Grant no. 4585. SDA.533. 052.J2).

\section{Competing Interests}

The authors declare that they have no competing interests.

\section{Publisher's Note}

Veterinary World (Publisher of International Journal of One Health) remains neutral with regard 
to jurisdictional claims in published institutional affiliation.

\section{References}

1. Dubey, J.P., Lago, E.G., Gennari, S.M., Su, C. and Jones, J.L. (2012) Toxoplasmosis in humans and animals in Brazil: High prevalence, high burden of disease, and epidemiology. Parasitology. 139(11): 1375-1424.

2. Moncada, P.A. and Montoya, J.G. (2012) Toxoplasmosis in the fetus and newborn: An update on prevalence, diagnosis and treatment. Expert Rev. Anti Infect. Ther., 10(7): 815-828.

3. Flegr, J., Prandota, J., Sovičková, M. and Israili, Z.H. (2014) Toxoplasmosis-a global threat. Correlation of latent toxoplasmosis with specific disease burden in a set of 88 countries. PloS One, 9(3): e90203.

4. Saadatnia, G. and Golkar, M. (2012) A review on human toxoplasmosis. Scand. J. Infect. Dis., 44(11): 805-814.

5. Liu, Q., Wang, Z.D., Huang, S.Y. and Zhu, X.Q. (2015) Diagnosis of toxoplasmosis and typing of Toxoplasma gondii. Parasit. Vectors, 8(292): 1-14.

6. Retmanasari, A., Widartono, B.S., Wijayanti, M.A. and Artama, W.T. (2017) Prevalence and risk factors for Toxoplasmosis in Middle Java, Indonesia. EcoHealth, 14(1): 162-170.

7. Tuda, J., Adiani, S., Ichikawa-Seki, M., Umeda, K. and Nishikawa, Y. (2017) Seroprevalence of Toxoplasma gondii in humans and pigs in North Sulawesi, Indonesia. Parasitol. Int., 66(5): 615-618.

8. Muflikhah, N.D., Supargiyono, and Artama, W.T. (2018) Seroprevalence and risk factor of toxoplasmosis in schizophrenia patients referred to Grhasia psychiatric hospital, Yogyakarta, Indonesia. Afr. J. Infect. Dis., 12(1): 76-82.

9. Ichikawa-Seki, M., Guswanto, A., Allamanda, P., Mariamah, E.S., Wibowo, P.E., Igarashi, I. and Nishikawa, Y. (2015) Seroprevalence of antibody to TgGRA7 antigen of Toxoplasma gondii in livestock animals from Western Java, Indonesia. Parasitol. Int., 64(6): 484-486.

10. Ganiem, A.R., Dian, S., Indriati, A., Chaidir, L., Wisaksana, R., Sturm, P., Melchers, W., van der Ven, A., Parwati, I. and van Crevel, R. (2013) Cerebral toxoplasmosis mimicking subacute meningitis in HIV-infected patients; a cohort study from Indonesia. PLoS Negl. Trop. Dis., 7(1): 1994.

11. Lestari, Y.D., Sitompul, R., Edwar, L. and Djoerban, Z. (2013) Ocular diseases among HIV/AIDS patients in Jakarta, Indonesia. Southeast Asian J. Trop. Med. Public Health, 44(1): 62-71.

12. Hill, D.E. and Dubey, J.P. (2013) Toxoplasma gondii prevalence in farm animals in the United States. Int. J. Parasitol., 43(2): 107-113.

13. Howe, D.K. and Sibley, L.D. (1995) Toxoplasma gondii comprises three clonal lineages: Correlation of parasite genotype with human disease. J. Infect. Dis., 172(6): 1561-1566.

14. Su, C., Shwab, E.K., Zhou, P., Zhu, X.Q. and Dubey, J.P. (2010) Moving towards an integrated approach to molecular detection and identification of Toxoplasma gondii. Parasitology, 137(1): 1-11.

15. Boothroyd, J.C. and Grigg, M.E. (2002) Population biology of Toxoplasma gondii and its relevance to human infection: Do different strains cause different diseases? Curr. Opin. Microbiol., 5(4): 438-442.

16. Switaj, K., Master, A., Skrzypczak, M. and Zaborowski, P. (2005) Recent trends in molecular diagnostics for Toxoplasma gondii infections. Clin. Microbiol. Infect., 11(3): 170-176.

17. Ajzenberg, D., Bañuls, A.L., Tibayrenc, M. and Dardé, M.L. (2002) Microsatellite analysis of Toxoplasma gondii shows considerable polymorphism structured into two main clonal groups. Int. J. Parasitol., 32(1): 27-38.

18. Saeij, J.P., Boyle, J.P. and Boothroyd, J.C. (2005)
Differences among the three major strains of Toxoplasma gondii and their specific interactions with the infected host. Trends Parasitol., 21(10): 476-481.

19. Bessières, M.H., Berrebi, A., Cassaing, S., Fillaux, J., Cambus, J.P., Berry, A., Assouline, C., Ayoubi, J.M. and Magnaval, J.F. (2009) Diagnosis of congenital toxoplasmosis: Prenatal and neonatal evaluation of methods used in Toulouse university hospital and incidence of congenital toxoplasmosis. Memorias Inst. Oswaldo Cruz, 104(2): 389-392.

20. Bártová, E. and Literák, I. (2004) K24 T. gondii isolate is a hybrid and has the virulence of lineage I isolates. Parasite (Paris, France), 11(2): 183-188.

21. Grigg, M.E. and Boothroyd, J.C. (2001) Rapid identification of virulent Type I strains of the protozoan pathogen Toxoplasma gondii by PCR-restriction fragment length polymorphism analysis at the B1 gene. J. Clin. Microbiol., 39(1): 398-400.

22. Apsari, I., Artama, W.S. and Damriyasa, I. (2012) Molecular diagnosis of Toxoplasma gondii based on the tachyzoite and bradyzoite stage specific genes in free-range chicken. $J$. Vet., 13(1): 14-19.

23. Subekti, D.T., Artama, W.T., Sulistyaningsih, E., Poerwanto, S.H., Sari, Y. and Bagaskoro, F. (2008) Kloning dan analisis hasil kloning gen GRA1 dari Takizoit Toxoplasma gondii Isolat Lokal. JITV, 13(1): 43-51.

24. Su, C., Zhang, X. and Dubey, J.P. (2006) Genotyping of Toxoplasma gondii by multilocus PCR-RFLP markers: A high resolution and simple method for identification of parasites. Int. J. Parasitol., 36(7): 841-848.

25. García-Alegría, A.M., Anduro-Corona, I., PérezMartínez, C.J., Guadalupe Corella-Madueño, M.A., Rascón-Durán, M.L. and Astiazaran-Garcia, H. (2020) Quantification of DNA through the nanodrop spectrophotometer: Methodological validation using standard reference material and Sprague Dawley rat and human DNA. Int. J. Anal. Chem., 2020(11): 1-9.

26. Grigg, M.E., Bonnefoy, S., Hehl, A.B., Suzuki, Y. and Boothroyd, J.C. (2001) Success and virulence in Toxoplasma as the result of sexual recombination between two distinct ancestries. Science, 294(5540): 161-165.

27. Burg, J.L., Grover, C.M., Pouletty, P. and Boothroyd, J.C. (1989) Direct and sensitive detection of a pathogenic protozoan, Toxoplasma gondii, by polymerase chain reaction. J. Clin. Microbiol., 27(8): 1787-1792.

28. Susanto, L. Supali, T. and Gandahusada, S. (2002) Penentuan konsentrasi minimal gen B1 dan gen p30 Toxoplasma Gondii yang Masih terdeteksi dengan reaksi rantai polimerase. Makara J. Health Res., 6(2): 64-70.

29. Kusumaningsih, P. (2018) Evaluasi Konstruksi DNA $\mathrm{Da}+$ Lam Vektor Plasmid Berkaitan Dengan Ekspresi Protein Rekombinan Rophtry-1 (ROP1) Toxoplasma Gondii Pada Eschericia coli. Seminar Ilmiah Nasional Teknologi, Sains, dan Sosial Humaniora, Bali.

30. Hou, S., Liu, Y., Tang, Y., Wu, M., Guan, J., Li, X., Wang, Z., Jiang, J., Deng, M., Duan, Z., Tang, X., Han, X. and Jiang, L. (2019) Anti-Toxoplasma gondii effect of two spider venoms in vitro and in vivo. Toxicon, 166(9): 9-14.

31. Tenter, A.M., Heckeroth, A.R. and Weiss, L.M. (2000) Toxoplasma gondii: From animals to humans. Int. J. Parasitol., 30(12-13): 1217-1258.

32. Tavassoli, M., Ghorbanzadehghan, M. and Esmaeilnejad, B. (2013) Foll detection of Toxoplasma gondii in sheep and goats blood samples by PCR-RFLP in Urmia. Vet. Res. Forum Int. Quart. J., 4(1): 43-47.

33. Fuentes, I., Rodriguez, M., Domingo, C.J., del Castillo, F., Juncosa, T. and Alvar, J. (1996) Urine sample used for congenital toxoplasmosis diagnosis by PCR. J. Clin. Microbiol., 34(10): 2368-2371.

34. Su, C., Evans, D., Cole, R.H., Kissinger, J.C., Ajioka, J.W. and Sibley, L.D. (2003) Recent expansion of toxoplasma through enhanced oral transmission. Science, 299(5605): 
$414-416$.

35. Khan, A., Dubey, J.P., Su, C., Ajioka, J.W., Rosenthal, B.M. and Sibley, L.D. (2011) Genetic analyses of atypical Toxoplasma gondii strains reveal a fourth clonal lineage in North America. Int. J. Parasitol., 41(6): 645-655.

36. López-Andreo, M., Lugo, L., Garrido-Pertierra, A., Prieto, M.I. and Puyet, A. (2005) Identification and quantitation of species in complex DNA mixtures by real-time polymerase chain reaction. Anal. Biochem., 339(1): 73-82.

37. Halonen, S.K. and Weiss, L.M. (2013) Toxoplasmosis. Handb. Clin. Neurol., 2013(114): 125-145.

38. Apsari, I.A.P. Artama, W.T. and Sumartono, I.M. (2012) Damriyasa. Sekuen gen surface antigen-1 dan bradizoit antigen-1 takizoit Toxoplasma gondii sebagai Kandidat Pemindai DNA. J. Vet., 13(4): 330-339.

39. Rahumatullah, A., Khoo, B.Y. and Noordin, R. (2012) Triplex PCR using new primers for the detection of Toxoplasma gondii. Exp. Parasitol., 131(2): 231-238.

40. Al-Hadraawy, S.K., Alzeyadi, M., Shakir, A.A. and Al-Dujaili, A.N. (2019) Detection of Toxoplasma gondii genotypes in abortion women by RFLP-PCR in Al-Najaf Al-Ashraf province. J. Phys. Conf. Ser., 1234(1): 012084.

41. Kotresha, D. and Noordin, R. (2010) Recombinant proteins in the diagnosis of toxoplasmosis. Acta Pathol. Microbiol. Immunol. Scand., 118(8): 529-542.

42. Shwab, E.K., Zhu, X.Q., Majumdar, D., Pena, H.F., Gennari, S.M., Dubey, J.P. and Su, C. (2014) Geographical patterns of Toxoplasma gondii genetic diversity revealed by multilocus PCR-RFLP genotyping. Parasitology, 141(4): 453-461.

43. Alfonso, Y., Fraga, J., Cox, R., Bandera, F., Pomier, O., Fonseca, C., Ginorio, D., Torres, G. and Capo, V. (2008) Comparison of four DNA extraction methods from cerebrospinal fluid for the detection of Toxoplasma gondii by polymerase chain reaction in AIDS patients. Med. Sci. Monit. Int. Med. J. Exp. Clin. Res., 14(3): 1-6.

44. Alfonso, Y., Fraga, J., Jiménez, N., Fonseca, C., DortaContreras, A.J., Cox, R., Capó, V., Bandera, F., Pomier, O. and Ginorio, D. (2009) Detection of Toxoplasma gondii in cerebrospinal fluid from AIDS patients by nested PCR and rapid identification of Type I allele at B1 gene by RFLP analysis. Exp. Parasitol., 122(3): 203-207.

45. Roszik, J., Fenyőfalvi, G., Halász, L., Karányi, Z. and Székvölgyi, L. (2017) In silico restriction enzyme digests to minimize mapping bias in genomic sequencing. Molecular therapy. Methods Clin. Dev., 6(9): 66-67.

46. Literák, I. and Rychlík I. (1999) Genome changes in the Toxoplasma gondii strains during laboratory passages in mice. Acta. Vet. Brno., 68(3): 203-208.

47. Chernukhin, V.A. Abdurashitov, M.A., Tomilov, V., Gonchar, D.A. and Degtyarev, S. (2006) Comparative restriction enzymes analysis of rat chromosomal DNA in vitro and in silico. Transl. Ovchinnikov Bull. Biotechnol. Phys. Chem. Biol., 2(3): 39-46.

48. Endrawati, D. and Kusumaningtyas, E. (2021) Molecular profile of Trichophyton mentagrophytes and Microsporum canis based on PCR-RFLP of internal transcribed spacer. JITV, 26(1): 1-12.

49. Hidayati, H., Saleh, E. and Aulaw, T. (2015) Identifikasi keragaman gen bmpr-1b (bone morphogenetic protein receptor $\mathrm{Ib}$ ) pada ayam arab, ayam kampung dan ayam ras petelur menggunakan PCR-RFLP. J. Peternakan UIN Sultan Syarif. Kasim., 13(1): 1-12.

50. Makula, R.A. and Meagher, R.B. (1980) A new restriction endonuclease from the anaerobic bacterium, Desulfovibrio desulfuricans, Norway. Nucleic Acids Res., 8(14): 3125-3131.

51. Hashim, H.O. and Al-Shuhaib, M.B.S. (2019) Exploring the potential and limitations of PCR-RFLP and PCR-SSCP for SNP detection: A review. J. Appl. Biotechnol. Rep., 6(4): 137-144.

52. Wang, Y. and Yin, H. (2014) Research progress on surface antigen 1 (SAG1) of Toxoplasma gondii. Parasit. Vectors, 7(180): 1-14

53. Ivovic, V., Marija Vujanic, M., Tijana, Š., Ivana, K. and Olgica, D.D. (2012) Molecular detection and genotyping of Toxoplasma gondii from clinical samples. Rec. Adv., 10(5772): 50830. 